\title{
Узкополосный непрерывный одномодовый волоконный эрбиевый лазер на 1550 нм мощностью 25 Вт с шириной спектральной линии 0.1 нм
}

\author{
А.А. Сурин ${ }^{1, *}$, Н.В. Коваленко ${ }^{1,2}$, Т.Е. Борисенко ${ }^{1}$, А.А. Мольков ${ }^{1,2}$, К.Ю. Прусаков ${ }^{1,2}$ \\ ${ }^{\prime}$ НТО “ИРЭ-Полюс”, Фрязино \\ ${ }^{2}$ Московский Физико-Технический Институт (ГУ), Москва \\ *E-mail: asurin@ntoire-polus.ru
}

DOI:10.31868/RFL2018.51-52

Мощный одномодовый лазер на 1550 нм с шириной линии порядка 0,1 нм представляет интерес для таких применений как бортовые системы сканирования [1] и в качестве накачки для дальнейшего преобразования излучения во вторую гармонику в кристаллах с периодической доменной структурой [2]. Рекордные мощности одномодовых непрерывных эрбиевых лазеров это сотни ватт при введении накачки в оболочку [3 - 297W] или сердцевине активного световода [4 $100 \mathrm{~W}]$. Но ширина спектральной линии этих лазеров обычно составляет несколько нанометров. Получение десятков ватт одномодового излучения $1550 \mathrm{Hм}$ с узкой линией в резонаторной схеме с эрбиевой активной средой ограничено низким порогом модовой нестабильности [5], а также нелинейными эффектами уширяющими линию, в особенности ЧВС [6].

Мы представляем подход получения узкополосного излучения на $1550 \mathrm{Hм}$, позволяющий обойти эти ограничения. Он заключается в одномодовой накачке в сердцевину активного иттербий-эрбиевого волокна на длине волны $1065 \mathrm{Hм} \mathrm{и}$ использовании волоконных решеток с узким спектром отражения. Оптическая схема эксперимента приведена на рис.1.

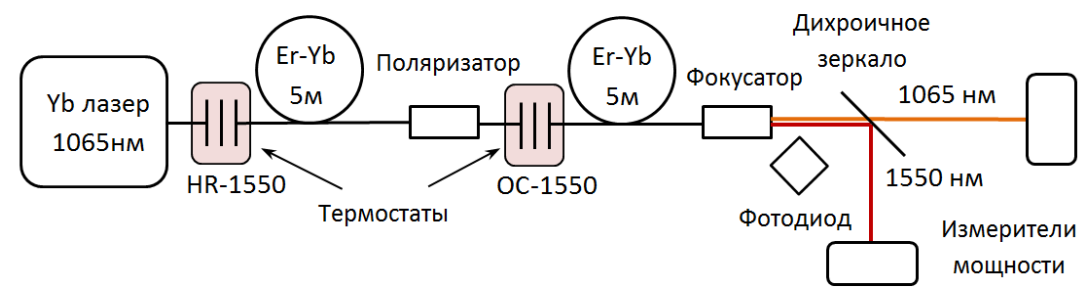

Рис.1. Оптическая схема узкополосного лазера на 1550 нм.

В данной схеме было продемонстрировано увеличение порога модовой нестабильности при накачке в сердцевину активного волокна по сравнению с многомодовой диодной накачкой. Другими особенными преимуществами данной схемы являются низкий уровень инверсии ионов иттербия в иттербий-эрбиевом волокне, как следствие повышение порога пичкования иттербия, а также использование моноволокна вместо «двойки».

Такая оптическая схема позволила получить 25 Вт излучения на длине волны 1550 нм с шириной линии 0,1нм. Полученные результаты приведены на рис.2. От дальнейшего повышения мощности накачки было решено отказаться из-за сильного разогрева волокна. После оптимизации потерь по накачке в этой схеме ожидается дальнейшее увеличение выходной мощности. 

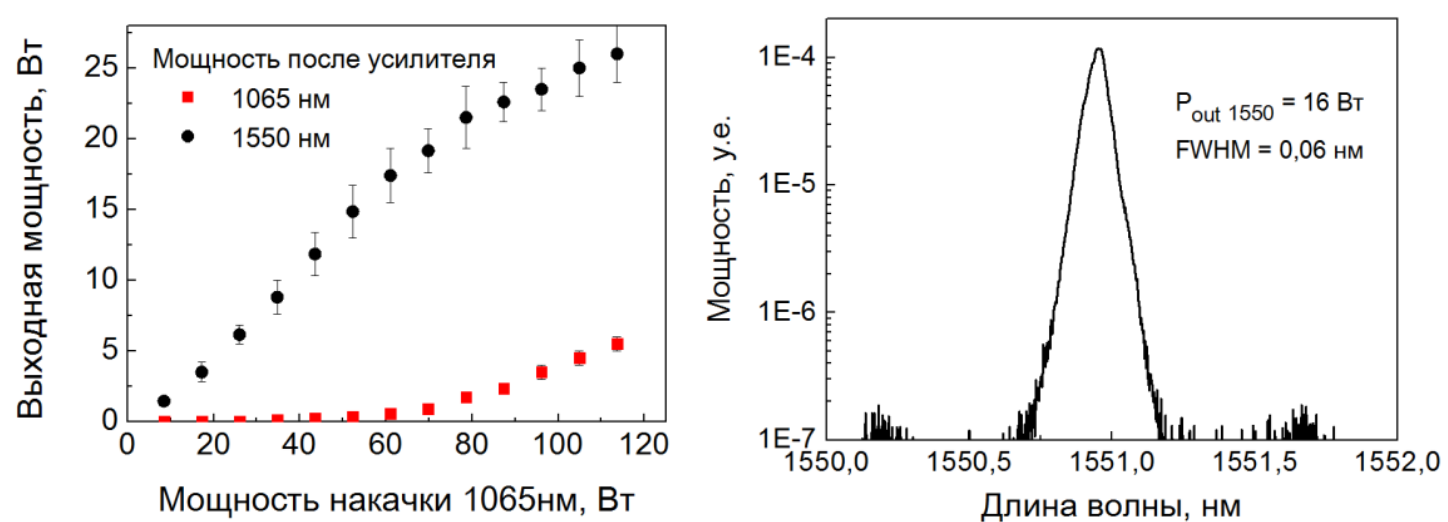

Рис.2. Зависимость полученной выходной мощности на 1550нм и остаточной накачки на 1065 нм от мощности накачки (слева) и спектр излучения на 1550 нм при 16Вт выходной мощности (справа).

Авторы выражают благодарность руководству НТО «ИРЭ-Полюс» за поддержку данных исследований.

\section{Литература}

[1] M. Pfennigbauer, A. Ullrich, ILMF, New Orleans, February 7-9, (2011).

[2] A.A. Surin, S.V. Larin, T.E. Borisenko, K.Yu. Prusakov and Yu.S. Stirmanov, Quantum Electronics 46(12), 1097 - 1101 (2016).

[3] Y. Jeong, S. Yoo, C.A. Codemard et al., IEEE J. Sel. Top. Quantum Electron., 13, 573, (2007).

[4] V.R. Supradeepa, J.W. Nicholson, K. Feder, CLEO Technical Digest CM2N.8, (2012)

[5] P.V. Puju, M.V. Zelenova, V.A. Tyrtyshnyy,17th International Conference «Laser Optics», WeS1A-21, (2016).

[6] S. P. Singh, N. Singh, Progress In Electromagnetics Research, 73, 249-275, (2007). 